\title{
Preliminary studies on the effect of bioactive substances of Hypnea musciformis (Wulf.) Lamour. on the growth of seedlings in green gram, Vigna radiata $\mathrm{L}$.
}

\section{Chitra Nil Gopalakrishnan ${ }^{1 *}$, Binumol T ${ }^{2}$}

${ }^{1}$ Department of Botany, Calicut University, Thrissur, Kerala, India, ${ }^{2}$ Department of Botany, Sree Narayana College, Nattika. Thrissur, Kerala, India

Received: 10.11 .2015

Revised: 16.12.2015

Accepted: 23.12 .2015

Published: 04.01.2016

*Address for correspondence: Chitra Nil Gopalakrishnan, Department of Botany, Calicut University, Thrissur, Kerala, India. E-mail: cprasadbalakrishnan@gmail. com

\begin{abstract}
The effect of seaweed liquid fertilizer (SLF) of Hypnea musciformis (wulf.) Lamour.was tested at different concentrations $(1,2,3$ and $4 \mathrm{~g} / \mathrm{ml})$ on seed germination and biochemical constituents of Vigna radiata L. The extracts promoted seed germination at lower levels of SLF application. The seeds treated with, $2 \mathrm{~g} / \mathrm{ml}$ concentration showed maximum seed germination, radicle length, hypocotyl length, seedling length, fresh weight, phytomass, productivity, phytotoxicity, and photosynthetic pigments like Chlorophyll A, B, and total chlorophyll. Moreover, the different extracts of seaweed were subjected to phytochemical screening. All the tested compounds (tannins, alkaloids, saponins, glycosides, and steroids) were present in varied degrees in Hypnea. The result of the present study can help in the identification and selection of raw materials in agriculture and drug industry.
\end{abstract}

KEY WORDS: Biochemical, Hypnea musciformis, phytochemical, seaweed liquid fertilizer, seed germination, Vigna radiata

\section{INTRODUCTION}

The fast growing population is mounting tremendous pressure on food production in the country. To meet out this increasing demand, farmers are using chemical fertilizers to enhance their crop production (Kumar and Dinabandhu, 2011). Application of chemical fertilizers certainly compensate the deficiency of nutrients in the soil. Whereas, in excess it affects soil and plants in due course (Sridhar and Rengasamy, 2010). Long-term use of synthetic chemical fertilizers will damage the physiochemical character, microflora and microecology of the soil. Chemical fertilizers are capable of killing off many of the soil organisms that are responsible for decomposition and soil formation. The adverse effect of inorganic fertilizers on soil and environment has led us to examine alternative biofertilizers.

Seaweed extract is a new generation of natural organic fertilizer containing highly effective nutritious component which promotes faster germination of seeds and increase yield and resistant capability of many crops (Kamaldhasan and Subramanian, 2009). Seaweed or marine macroalgae are the primitive group of organisms with no roots, stems, and leaves, and they are one of the important marine living resources with tremendous commercial uses (Pise and Sabale, 2010; Zodape et al., 2008). They form an integral part of marine coastal ecosystems. In recent times seaweed extracts are being used as fertilizers. These extracts are commonly known as seaweed liquid fertilizers (SLF).

Liquid fertilizers derived from seaweeds are found to be superior to chemical fertilizers due to a high level of organic matter, macro and micro nutrients, amino acids, vitamins, cytokinins, auxin and abscisic acid like growth promoting substances (Kavipriya et al., 2011; Sasikumar et al., 2011). Liquid seaweed fertilizer is a unique combination of $\mathrm{N}, \mathrm{P}, \mathrm{K}$, trace elements, alginates and simple sugars that are in dissolved form. They are 
easily absorbed through roots and leaves, and also help in degradation which release trace elements bound to the soil (Chapman and Chapman, 1980; Thivy, 1982).

Unlike chemical fertilizers, extracts derived from seaweeds are biodegradeble, non-toxic, non-polluting and nonhazardous to humans, animals and birds (Dhargalkar and Pereira, 2005). Recent researchers proved that seaweed fertilizers are very economic, cheap and eco-friendly. Seaweed extracts are now available commercially and are labeled as Maxi crop, Algifert, Geomar GA14, Kelpak 66, Seaspray, Seasoil, SM3, Seacrop16, Cytex, Cytokin, Algistim, Biozyme, Seamac and Alginex and MAC (Sridhar and Rengasamy, 2010).

The present study is carried out to determine the effect of bioactive substances from Hypnea musciformis (Wulf.) Lamour. (red algae) on seed germination and biochemical constituents of green gram, Vigna radiata L.

\section{MATERIALS AND METHODS}

\section{Collection of Seaweeds}

The seaweeds used in the present study was $H$. musciformis (Wulf.) Lamour. belonging to the class Rhodophyceae. They were collected from coastal areas of Thikkodi, Kerala. The algal species were handpicked and washed thoroughly with sea water to remove all unwanted impurities, adhering sand particles and epiphytes. Morphologically distinct thalli of H. musciformis (Wulf.) Lamour. was placed in polythene bags and transported to the laboratory. The samples were washed thoroughly using tap water to remove the surface salt and then spread on blotting paper to remove excess water.

\section{Preparation of Seaweed Liquid Extract}

Seaweeds were shade-dried for 2-5 days. The dried seaweeds were cut into small pieces and made into powder. The powdered seaweeds were extracted with water and were made into different concentrations $(1,2,3,4 \mathrm{~g} / \mathrm{ml})$ by adding water. It was used for finding the effect on seed germination. As the liquid fertilizer contains organic matter, it was refrigerated until use.

\section{Selection of Seeds}

The seeds selected for the present study was green gram (V. radiata L.) belonging to the family Leguminosae. The seeds selected from healthy looking plants growing in household regions, free from pollution were used. The seeds with uniform size and weight were chosen for the experiment purpose. Seeds were pre-soaked in distilled water. The viable seeds selected were used for the germination studies

\section{Germination Studies}

The germination study was conducted in March. They were maintained under room temperature for $24 \mathrm{~h}$. Sterilized petridishes are used for this treatment, and the concentration taken was $1,2,3$ and $4 \mathrm{~g} / \mathrm{ml}$. The petridishes were taken and are lined with Whatman No.1 filter paper. Triplicates of each treatment including control were maintained. The seeds were treated with varying concentration of SLF in equal amounts. The treated seeds were kept under observation for 3 days. The emergence of radicle was considered as the criteria for germination. The percentage of germination, radicle, and hypocotyl length were noted from the $1^{\text {st }}$ to $3^{\text {rd }}$ day of observation.

Under germination studies, germination percentage (Vilasini, 1978), radicle and hypocotyls length, vigor index (Sharma and Saran, 1992), growth index, phytotoxicity (Chou and Mullar, 1972), fresh weight and dry weight of seedlings. Phytomass and productivity were analyzed.

\section{Biochemical Studies}

In biochemical study photosynthetic pigments such as Chlorophyll A, Chlorophyll B and total chlorophyll were estimated in control and in treated plants (Arnon, 1949). It is done on the $7^{\text {th }}$ day of the experiment.

\section{Phytochemical Studies}

The powdered seaweed sample was extracted with methanol, chloroform, and water. The different extracts were tested for tannins, alkaloids, saponins, glycosides and steroids (Harborne, 1998).

\section{Statistical Analysis}

Data were analyzed statistically for standard deviation.

\section{RESULT}

Germination percentage varies from $95.56 \%$ to $100 \%$. The highest germination percentage was observed in lower concentrations. The maximum germination percentage $(100 \%)$ was observed in $2 \mathrm{~g} / \mathrm{ml}$ concentration and least germination $(95.56 \%)$ in $4 \mathrm{~g} / \mathrm{ml}$ concentration. Radicle length, hypocotyl length, seedling length were also observed maximum at $2 \mathrm{~g} / \mathrm{ml}$ concentration of SLF. The vigor index (9.13) and growth index were observed maximum at same concentration (Figures 1 and 2). The value of phytotoxicity in 1, 2, 3 and $4 \mathrm{~g} / \mathrm{ml}$ concentration was found to be $10.38,-24.03$, 
-15.03 , and -8.60 respectively (Figure 3 ). The negative value for phytotoxicity reflects the tolerance of the plant.

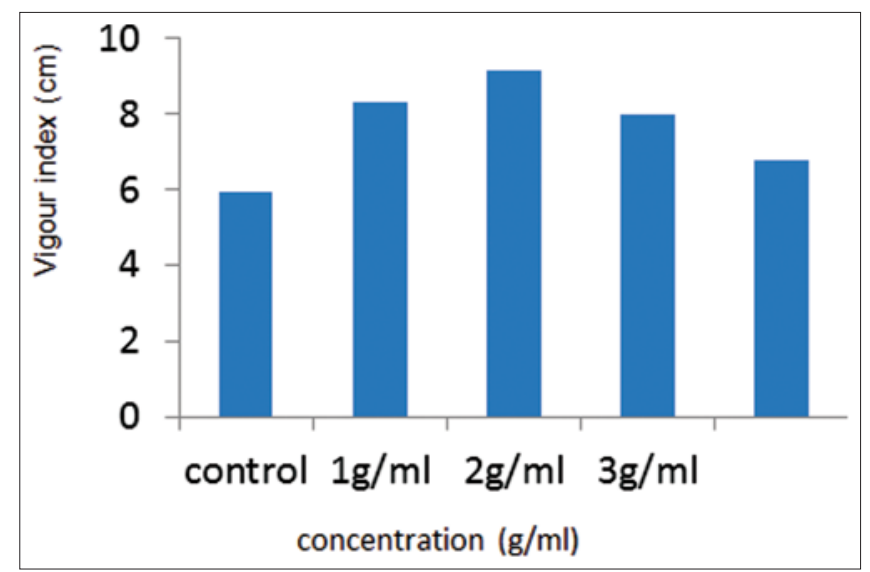

Figure 1: Vigor index

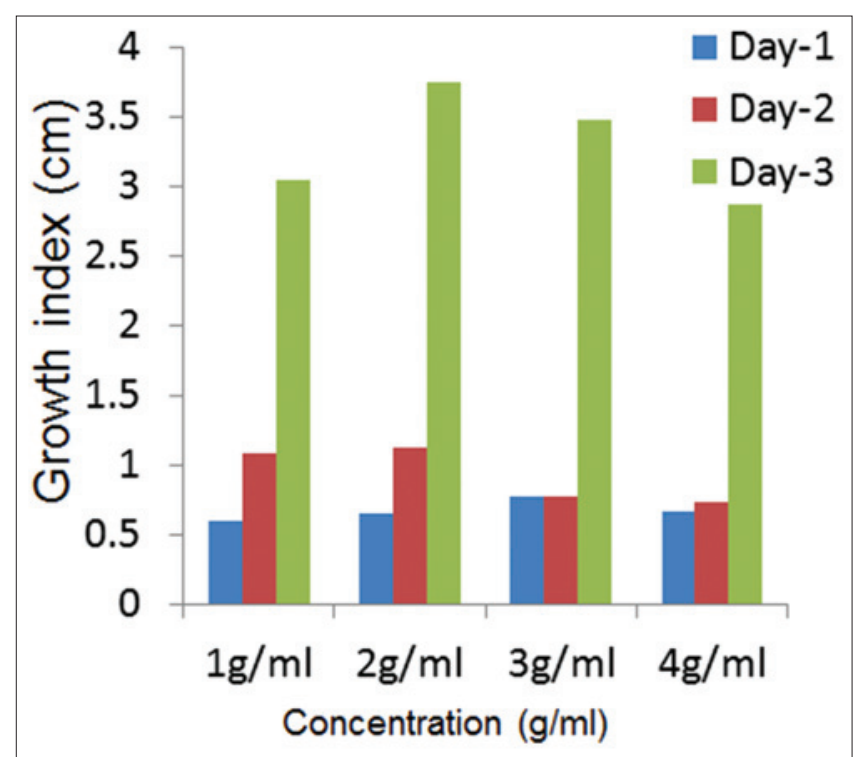

Figure 2: Growth index

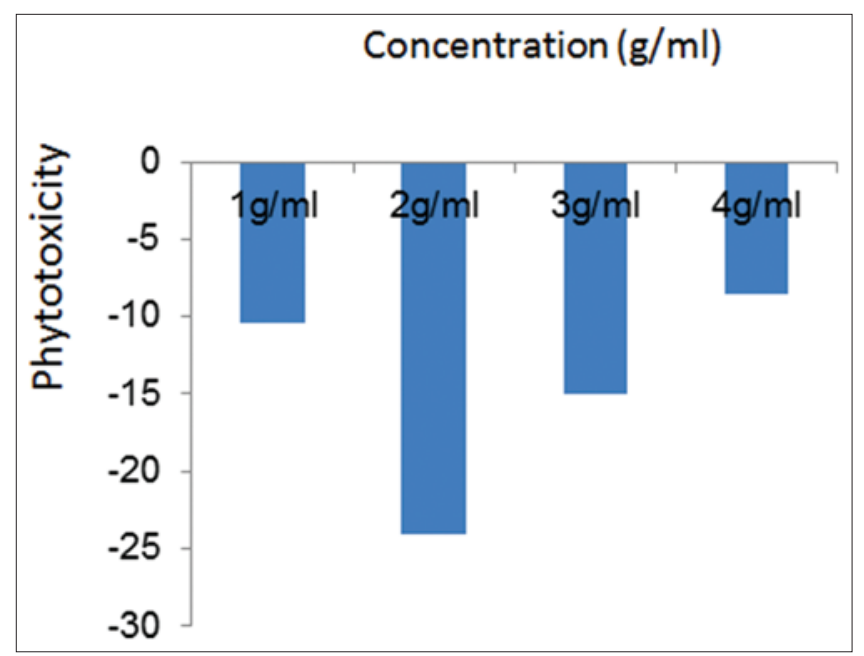

Figure 3: Phytotoxicity
The maximum phytomass (2.74) and productivity (0.91) was found at $2 \mathrm{~g} / \mathrm{ml} \mathrm{SLF}$ and minimum was observed at control (Table 1).

The seedlings treated in lower concentrations like 1 and $2 \mathrm{~g} / \mathrm{ml}$ were used in the biochemical studies because the leaves are present only in those concentrations. Maximum value of Chlorophyll A was observed at $2 \mathrm{~g} \mathrm{ml}$ concentration of $H$. musciformis (Wulf.) Lamour. and the value was found to be $2.23 \mathrm{mg} / \mathrm{ml}$. The minimum Chlorophyll A was observed at control and the value was found to be $0.36 \mathrm{mg} / \mathrm{ml}$. The maximum Chlorophyll B was observed at $2 \mathrm{~g} / \mathrm{ml}$ SLF of $H$. musciformis (Wulf.) Lamour. and the value was found to be $2.68 \mathrm{mg} / \mathrm{ml}$. The minimum chlorophyll-b was observed at control, and the value was found to be $0.43 \mathrm{mg} / \mathrm{ml}$ (Figure 4).

Preliminary phytochemical analysis of five different chemical compounds (tannins, alkaloids, saponins, glycosides, and steroids) was tested in three different

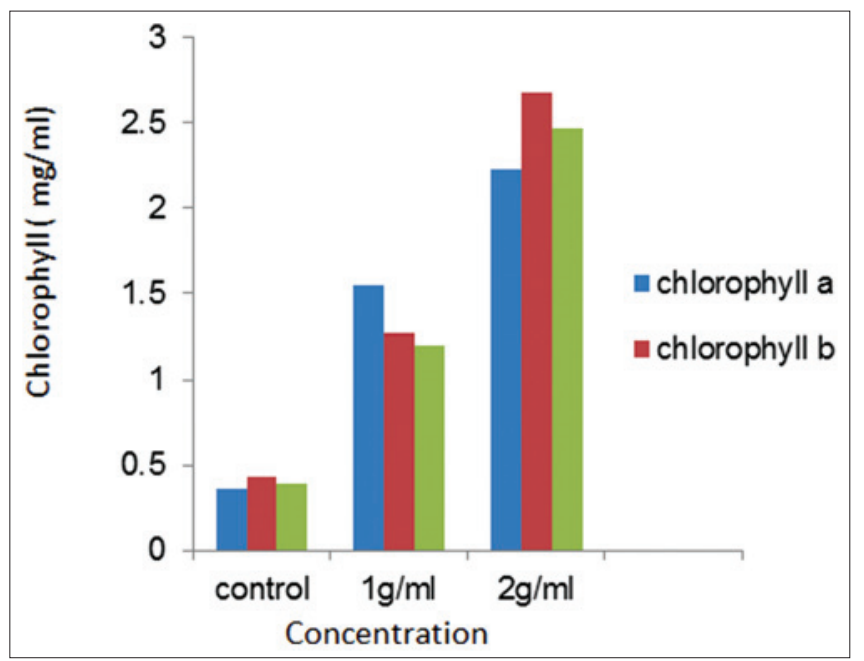

Figure 4: Effect of Hypnea on photosynthetic pigments

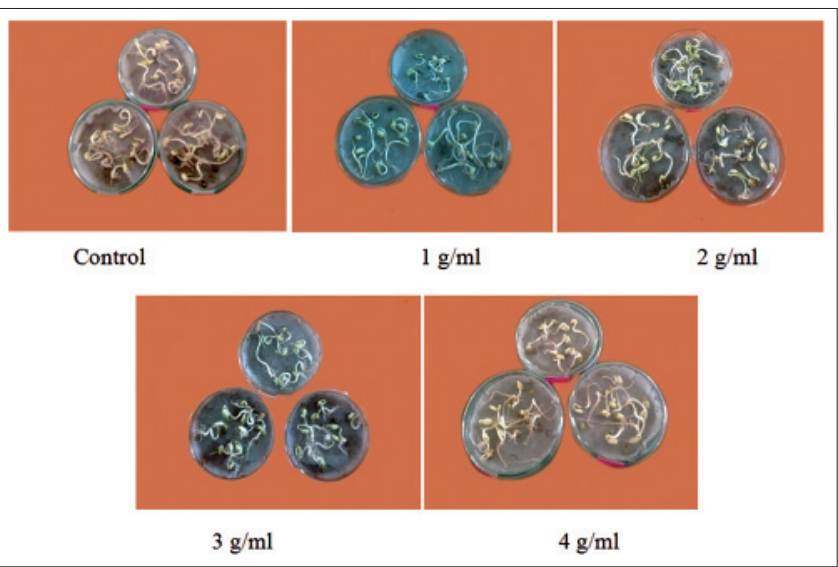

Plate 1: Effect of seaweed extract on germination of Vigna radiata.L 
Table 1: Effect of $H$. musciformis (Wulf.) Lamour. SLF on seed germination in $V$. radiata L.

\begin{tabular}{|c|c|c|c|c|c|}
\hline \multirow[t]{2}{*}{ Parameters } & \multicolumn{5}{|c|}{ Concentrations } \\
\hline & Control & $1 \mathrm{~g} / \mathrm{ml}$ & $2 \mathrm{~g} / \mathrm{ml}$ & $3 \mathrm{~g} / \mathrm{ml}$ & $4 \mathrm{~g} / \mathrm{ml}$ \\
\hline Germination percentage & $97.78 \pm 0.41$ & $98.89 \pm 0.31$ & $100 \pm 0.31$ & $96.67 \pm 0.67$ & $95.56 \pm 0.50$ \\
\hline Radicle length $(\mathrm{cm})$ & $3.37 \pm 0.43$ & $3.72 \pm 0.54$ & $4.18 \pm 0.01$ & $3.88 \pm 0.15$ & $3.66 \pm 0.74$ \\
\hline Hypocotyl length $(\mathrm{cm})$ & $2.67 \pm 0.99$ & $4.66 \pm 0.45$ & $4.95 \pm 0.1 .10$ & $4.39 \pm 0.97$ & $3.42 \pm 0.13$ \\
\hline Seedling length $(\mathrm{cm})$ & $6.04 \pm 1.42$ & $8.39 \pm 0.39$ & $9.13 \pm 1.17$ & $8.27 \pm 1.12$ & $7.08 \pm 0.62$ \\
\hline Fresh weight (g) & 2.46 & 2.92 & 3.15 & 3.01 & 2.89 \\
\hline Dry weight (g) & 0.51 & 0.46 & 0.41 & 0.45 & 0.53 \\
\hline Phytomass & 1.95 & 2.46 & 2.74 & 2.56 & 2.38 \\
\hline Productivity & 0.65 & 0.82 & 0.91 & 0.85 & 0.79 \\
\hline
\end{tabular}

H. musciformis: Hypnea musciformis, V. radiate: Vigna radiate, SLF: Seaweed liquid fertilizer

Table 2: Preliminary phytochemical analysis of crude extracts of $H$. musciformis (Wulf.) Lamour.

\begin{tabular}{lccc}
\hline Phytochemical & Water & Methanol & Chloroform \\
\hline Tannins & +++ & - & - \\
Alkaloids & +++ & - & - \\
Glycosides & ++ & ++ & - \\
Steroids & - & +++ & ++ \\
Saponins & ++ & - & +++ \\
\hline
\end{tabular}

H. musciformis: Hypnea musciformis

extracts of $H$. musciformis (Wulf.) Lamour. Thus, out of $5 \times 3=15$ tests for the presence or absence of the above compounds, 8 tests gave positive results and the remaining 7 -gave negative results (Table 2 and Plate 1).

The eight positive results show the presence of tannins, alkaloids, saponins, glycosides, and steroids with varied degree. The saponins, glycosides, and steroids showed the maximum presence in two different extracts followed by tannins and alkaloids in one extract. Among the three different extracts, aqueous extract showed the presence of a maximum number of four compounds. Next to that methanol and chloroform showed only two compounds.

\section{DISCUSSION}

The seaweed extracts obtained from seaweeds are known to contain several folds of nutrients available in their habitats. From time immemorial, the nutrients in the land are being leached into the ocean through rains, rivers, etc. Utilization of seaweed as SLF is one of the excellent means to get the lost nutrients back to the land. Application of SLF plays a significant role in improving the yield of crop plants by about $20-30 \%$. In the present study, the SLF obtained from the red seaweed $H$. musciformis (Wulf.) Lamour. and V. radiata L. elucidated certain interesting findings.

From the present investigation, it is clear that algal extract of H. musciformis (Wulf.) Lamour. at low concentration promotes the growth and biochemical constituents in
V.radiata $\mathrm{L}$. In the study the percentage of seed germination was found to be $100 \%$ in plants which received $2 \mathrm{~g} / \mathrm{ml}$ SLF. This is in accordance with the earlier reports. The lower concentration of seaweed extracts showed increased seed germination on ornamental plants, tobacco, pea and cotton (Aitken and Senn, 1965). SLF treatment enhanced the rate of seed germination in green chilies and turnip and found that lower concentrations of SLF increase the germination percentage than the higher concentrations (Dhargalkar and Untawale, 1983).

The present study revealed that low concentration $(2 \mathrm{~g} / \mathrm{ml})$ of the seaweed extract of $H$. musuciformis (Wulf.) Lamour. accelerated the growth parameters such as shoot length, root length and dry weight of seedlings. The highest radicle length, hypocotyl length, seedling length, fresh weight, phytomass, and productivity were recorded maximum at $2 \mathrm{~g} / \mathrm{ml}$ extract of $H$. musciformis (Wulf.) Lamour. soaked seeds and the higher concentrations showed a decreasing trend. In Dictyota dichotoma which induced maximum seedling growth at lower concentrations in Abelmoschus esculantus (Sasikumar et al., 2011). The use of biostimulants could induce an increase in membrane permeability by an increment in permeases, specific enzyme protein carrier molecules in the membrane or a higher and improved activity of existing carriers (Berlyn and Sivaramakrishnan, 1996). The role of biostimulants in plant growth enhancement is still unclear, mainly due to the multitude of products and composition and to the fact that the effects of biostimulant application seem to be species related (Chitra and Sreeja, 2013).

In the present work, Chlorophyll A, B and total chlorophyll increased under the application of seaweed extracts. The application of Ascophyllum extract increased the chlorophyll content of cucumber cotyledons and tomato (Wapham et al., 1993). Besides, seaweed extract regulated the plant bio-physiological activities, which collectively resulted in maintaining higher photosynthetic activity (Sing and Chandel, 2005). Damage to membrane, one of the suggested explanations for the loss of viability 
during ageing (Roberts, 1972) is the reflection of seed deterioration accompanied by alterations in the membranes of aged seeds (Parrish and Leopld, 1978). The germination percentage and seedling growth are reduced in higher concentration. This may be due to the feedback inhibition of enzymes in metabolism. Lower doses of seaweed extract strongly induced the growth in chlorophyll as high doses gave negative result. The effect of extracts from algae on the chlorophyll content in leaves is not identical, and many authors confirm a close relation between the process of formation of the chlorophyll dye and the dose of seaweed extracts (Jothinayagi and Anbazhagan, 2009).

The seaweeds are rich in secondary metabolites which include alkaloids, glycosides, flavonoids, saponins, tannins, steroids and related active metabolites, which are of great medicinal value and have been extensively used in the drug and pharmaceutical industry (Eluvakkal et al., 2010). In the present study, observations directly coincided with the previous observations. The presence of alkaloids, glycosides, steroids, tannins, and saponins in the crude extracts of $H$. musciformis (Wulf.) Lamour. suggest that seaweeds can be used as a anti-microbial, anti-parasitic, anti-inflammatory, anti-feedent, anti-oxidant, antiallergenic, anti-thrombic, anti-carcinogenic and anti-ulcer agents in the near future.

\section{CONCLUSION}

This experiment was an attempt to analyze the effect of SLF of H. musiciformis (Wulf.) Lamour. in the seed germination and biochemical constituents of green gram (V. radiata L.).

The present investigations reveal that seaweed species are potential raw materials for fertilizer and drug production. Present findings encourage the application of seaweeds as a natural fertilizer in the agricultural sector as well as in drug production. Hence, the farmers might be advised to make use of SLF for better productivity of the plants and sustainable yield. One can prefer the seaweed extract to increase the soil fertility and crop productivity. Thus, preliminary studies on seed germination and phytochemical analysis of $H$. musciformis (Wulf.) Lamour. can help the manufacturers for identification and selection of raw materials for agriculture and drug industry.

\section{REFERENCES}

Aitken JB, Senn TL. Seaweed products as a fertilizer and soil conditioner. Bot Mar 1965;8:144-8.
Arnon DI. Copper enzymes in isolated chloroplasts, polyphenoxidase in Beta vulgaris. Plant Physiol 1949;24:1-15.

Berlyn GP, Sivaramakrishnan S. The use of organic biostimulants to reduce fertilizer use, increase stress resistance and promote growth. National Proceedings Forest and Conservation Nursery Association Meeting. Department of Agriculture, Forest service, Pacific Northwest Research Station. Portland, USA. 1996. p. 106-112.

Chapman VJ, Chapman DJ. Seaweed and their Uses. $3^{\text {rd }} \mathrm{ed}$. London: Chapman \& Hall Ltd; 1980. p. 327.

Chitra G, Sreeja PS. A comparative study on the effect of seaweed liquid fertilizers on the growth and yield of Vigna radiata. (L). Nat Environ Poll Tech 2013;12:359-62.

Chou CH, Mullar CH. Allelopathic mechanism of Archotostathylous glandulosa Var. Zacaensis. Am Middle Naturalis 1972;88:324-47.

DhargalkarVK, Untawale AG. Some observations on the effect of SLF on higher plants. Indian J Mar Sci 1983;12:210-4.

Dhargalkar VK, Pereira N. Seaweed: Promising plant of the millennium. Sci Cult 2005;71:60-6.

Eluvakkal T, Sivakumar SR, Arunkumar K. Fucoidan in some Indian brown seaweed along the Gulf of Mannar. Int J Bot 2010;6:176-81.

Kumar G, Dinabandhu S. Effect of seaweed liquid extract on growth and yield of Triticum aestivum var. Pusa Gold. J Appl Phycol 2011;23:251-5.

Harborne JB. Phytochemical Methods. A Guide to Modern Techniques of Plant Analysis. $3^{\text {rd }}$ ed. New York: Chapman and Hall; 1998. p. 1-150.

Jothinayagi N, Anbazhagan C. Effect of seaweed liquid fertilizer of Sargassum wightii on growth and biochemical characteristics of Abelmoschus esculentus (L.). medicus. Recent Res Sci Technol 2009;1:155-8.

Kamaldhasan N, Subramanian SK. Influence of seaweed liquid fertilizers on legume crop, red gram. J Basic Appl Biol 2009;3:21-4.

Kavipriya R, Dhanalakshmi PK, Jayashree S, Thangaraju N. Seaweed extract as a bio stimulant for legume crop, green gram. J Eco Biotech 2011;3:16-9.

Parrish DJ, Leopld AC. On the mechanism of ageing of soybean seeds. Plant Physiol 1978;61:365-8.

Pise NM, Sabale AB. Effect of seaweed concentrates on the growth and biochemical constituents of Trigonella foenum - Graecum L. J Phytol 2010;2:50-6.

Roberts EH, editor. Viability of Seeds. London: Chapman and Hall; 1972. p. 24-58.

Sasikumar K, Govidan T, Anuradha C. Effect of seaweed liquid fertilizer of Dictyota dichotoma on growth and yield of Abelmoschus esculantus. Eur J Exp Biol 2011;1:223-7.

Sharma AK, Saran B. Effect of salinity on germination and 
seedling growth in black gram. Neobotanica 1992;2:52-7. Singh PK, Chandel AS. Effect of biozyme on yield and quality of wheat (Triticum aestivum). Indian J Agron 2005;50:58-60.

Sridhar S, Rengasamy R. Studies on effect of seaweed liquid fertilizer on the flowering plant Tagetes erecta in the field trial. Adv Biores 2010;1:29-34.

Thivy F. On the importance and prospects of seaweed utilization in India. Seaweed Res Ulilin 1982;4:53-60.
Vilasini G. Mutagenic studies in Lathyrus sativus L. Ph.D. Thesis Osmania University. 1978.

Wapham CA, Bluden G, Jemkin T, Henkins SD. Significance of betaines in the increased cholorophyll content of plants treated with seaweed extract. J Appl Phycol 1993;5:231-4.

Zodape ST, Kawarkh VJ, Potolia JS, Warade AD. Effect of liquid seaweed fertilizer on yield and quality of okra. Abelmouschus esculentus (L). J Sci Indian Res 2008;67:1115-7. 